\title{
Chlorite composition and geothermometry: a comparative HRTEM/AEM-EMPA-XRD study of Cambrian basic lavas from the Ossa Morena Zone, SW Spain
}

\author{
A. LÓPEZ-MUNGUIRA ${ }^{1, *}$, F. NIETO ${ }^{2}$ AND D. MORATA ${ }^{3}$ \\ ${ }^{1}$ Área de Cristalografía y Mineralogía, Facultad de Ciencias, Universidad de Extremadura, Avda. de Elvas s/n, 06071 \\ Badajoz, Spain, ${ }^{2}$ Departamento de Mineralogía y Petrología y I.A.C.T., Universidad de Granada-CSIC, Avda. \\ Fuentenueva s/n, 18002, Granada, Spain, and ${ }^{3}$ Departamento de Geología, Facultad de Ciencias Físicas y \\ Matemáticas, Universidad de Chile, Plaza Ercilla 803, Santiago de Chile, Chile
}

(Received 5 April 2001; revised 22 September 2001)

\begin{abstract}
Chlorites from Cambrian basaltic vesicular lavas, characterize d by relatively high $X_{\mathrm{c}}$ (0.81-0.98), gave temperatures of formation of 285 to $350^{\circ} \mathrm{C}$ (Cathelineau's empirical geothermometer). Both the $X_{\mathrm{c}}$ and temperature calculations gave results which were too high for the diagenetic conditions indicated by the interbedded shale mineralogy. The HRTEM and XRD studies indicate the absence of smectite layers in these chlorites; i.e. according to lattice images, the actual value of $X_{\mathrm{c}}$ is 1 . The chlorite composition in these basaltic lavas must, therefore, be explained in relation to their whole-rock geochemistry, with which a good correlation has been found. The basaltic lavas are characterize d by relatively high $\mathrm{FeO} / \mathrm{MgO}$ ratios $(3.28 \pm 1.66)$ and must be considere d as an Fe-rich system, with similar chemical behaviour to pelitic rocks. In these cases, direct chlorite formation, without a previous smectite precursor, is a normal occurrence and the $X_{\mathrm{c}}$ calculation and empirical geothermometric calculation $\mathrm{s}$ are inadequate.
\end{abstract}

KEYWORDS: chlorite, metabasites, very low-grade metamorphism, chemical composition, thermometry.

The transition from smectite to chlorite in very lowgrade metabasites is a widely recorded and studied mineral transformation. With increasing metamorphic grade, the smectite content decreases until finally metabasites containing almost pure chlorite are produced (see Schiffman \& Day, 1999 and references therein). This important transformation has mostly been used to quantify the temperature of the very low-grade metamorphism in basaltic systems, using different methods to evaluate the smectite content of the mafic phyllosilicates. In this sense, the chlorite composition has been used as a much-criticized quantitative geothermometer. A review by de Caritat et al.

* E-mail: munguira@unex.e s DOI: $10.1180 / 0009855023720033$
(1993) showed that there are two types of chlorite geothermometer. The first is based on variations in chemical composition, as determined by thermodynamic analysis of specific reactions (Walshe, 1986; Hutcheon, 1990). The second is based on empirical calibrations of compositional variation (Al content of chlorite) as a function of a known increase in temperature (Cathelineau \& Nieva, 1985, Cathelineau, 1988; Kranidiotis \& McLean; 1987, Jowett, 1991; Aagaard \& Jahren, 1992). This second type of empirical geothermometer is used widely in a semiquantitative sense from direct chlorite electron microprobe analyses with relatively good results (e.g. Aguirre et al., 2000; Frimmel, 1997; Schmidt \& Robinson, 1997; Zang \& Fyfe, 1995). Nevertheless, de Caritat et al. (1993) applied several of the geothermometers to 
their chemical data and compared the results, obtaining poor correlation. Shau et al. (1990), Jiang et al. (1994) and Schmidt et al. (1999) showed that in chemical analyses, fine-grained chlorites are usually contaminated by the presence of a dioctahedral phase (smectite). They concluded that the $\mathrm{Al}$ content in chlorite varies in relation to the grade, but non-quantitatively. Finally, Essene \& Peacor (1995) and Merriman \& Peacor (1999) reported that all proposed chlorite geothermometers must be considered to be inaccurate in the measurement of temperature and should be applied with extreme caution.

Together with increasing metamorphic grade, the chemical composition of the system is also invoked to explain the chemical composition of chlorite. Along these lines, a recent paper by Xie et al. (1997) found a strong correlation between chlorite composition and the $\mathrm{MgO}$ content of the host rocks; they introduced a modification in Cathelineau's (1988) equation depending on the $\mathrm{Fe} /(\mathrm{Fe}+\mathrm{Mg})$ value of the chlorite composition. Zane et al. (1998) also emphasized the influence of the bulk rock composition on chlorite composition and that its use as a geothermometer should therefore be restricted.

On the other hand, chlorite polytypism is considered to change as a function of metamorphic grade. Generally, there is an increase in stacking order with increasing grade, consistent with a trend toward equilibrium (Schmidt \& Livi, 1999), but there is no correlation with temperature (Walker, 1993, de Caritat et al., 1993).

The aim of this work was to study the chlorites from vesicular basaltic lavas which are intercalated in a Cambrian very low-grade metapelitic sequence from SW Spain. High-resolution transmission electron microscopy (HRTEM) analyses were used to quantify the smectite layers in these chlorites, where present, thus allowing the correct characterization of the chlorites. Using other analytical techniques, we applied the proposed empirical geothermometers and contrasted the results with the metamorphic grade obtained from the pelitic rocks. A relationship between the chlorite composition and the host whole-rock geochemistry is proposed.

\section{GEOLOGICAL SETTING AND PETROLOGY}

Cambrian rocks from the Zafra area (Badajoz, Spain) are located in the Ossa-Morena Zone (Julivert et al., 1974). They comprise clastic - mainly terrigenous sediment - and volcanic rocks (Fig. 1). Shales and sandstones dominate in the Lower Cambrian, whereas the Middle-Upper Cambrian comprises shales and fine-grained sandstones with interbedded mostly basic and some acidic volcanic rocks. The volcanic rocks include both pyroclastic ash flows (ignimbrites) and basic lava flows. Sagredo \& Peinado (1992) interpreted these volcanic rocks as having an alkaline affinity, emplaced in clastic subtidal and shallow submarine environments on an extensional passive continental margin.

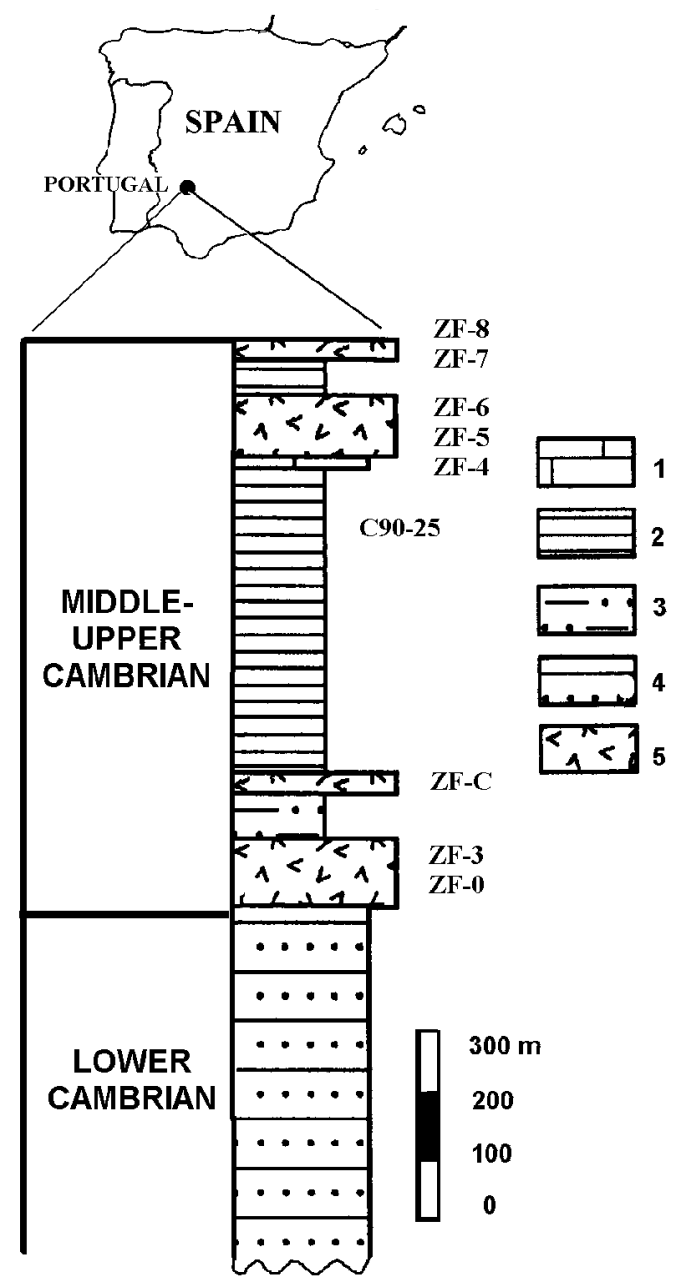

FIG. 1. Stratigraphic profile and location of the study area. 1: limestones; 2: shales; 3: shales and minor sandstones; 4: shales and siltstones; 5: volcanic rocks. Data from Liñán et al. (1995). Geological map from López-Munguir a et al. (1998). 
Previous studies of phyllosilicates, from the clastic rocks, were carried out by López-Munguira et al. (1993, 1996 and 1998) and López-Munguira \& Nieto (2000). X-ray diffraction (XRD), scanning electron microscopy (SEM), electron microprobe (EMPA) and transmission electron microscopy (TEM) indicated a temperature evolution in these clastic lithologies. Temperatures and pressure decreased from the basal Cambrian (epizone conditions, illite crystallinity $(\mathrm{IC})=0.25 \pm 0.04 ; b$ $=9.033 \pm 0.006 \AA$ ) to the Middle-Upper Cambrian (diagenetic conditions, IC $=0.50 \pm 0.07 ; b=$ $8.997 \pm 0.005 \AA$ ) and the Lower Cambrian exhibits anchizone conditions ( $\mathrm{IC}=0.38 \pm 0.05 ; \quad b=$ $9.011 \pm 0.005 \AA)$. The textural differences between the diagenetic zone, anchizone and epizone include a progressive increase in the size of dioctahedral K-rich mica grains, which involves an increased illite crystallinity based on the Kübler index. These micas are illite in the diagenetic zone and anchizone, and phengite in the epizone.

The basic volcanic (vesicular lavas and vesicular lava-breccias) rocks have undergone very low-grade alteration, with the formation of chlorite, various types of silica, and calcite as the main secondary minerals (López-Munguira et al., 1998). These secondary minerals are primarily found in amygdales and in the groundmass. Minor secondary minerals (chlorite, calcite and small white-mica crystals) are also present in some plagioclase phenocrysts. Plagioclase phenocrysts show pervasive albitization (An $<10 \%$ ), but index calcsilicates are absent due to the high $a \mathrm{CO}_{2}$ conditions during metamorphism (López-Munguira et al., 1998). According to these authors, the proportion of chlorite $v s$. smectite layers $\left(X_{\mathrm{c}}\right)$, determined from chlorite electron microprobe analyses, increases from 0.81 (sample ZF-8, Fig. 1) at the top of sequence to 0.91 (sample ZF-3, Fig. 1) in the Middle-Lower Cambrian boundary.

\section{MATERIALS AND METHODS}

A total of eight representative samples, corresponding to four basic vesicular lava flows of the Middle-Upper Cambrian (Fig. 1), were selected for this study. Samples ZF-0 and ZF-3 were selected from the lower lava flow (Lower-Middle Cambrian boundary), $\sim 100 \mathrm{~m}$ thick. Over this flow, and separated by $40-50 \mathrm{~m}$ of shales and siltstones, a thinner $(\sim 30 \mathrm{~m})$ lava flow is present (sample ZF-C). Close to the Middle-Upper Cambrian boundary, a thick ( 100 m) lava flow was sampled (samples ZF-4, ZF-5 and ZF-6). Finally, samples ZF-7 and $\mathrm{ZF}-8$ were selected from the uppermost lava flow ( $\sim 30 \mathrm{~m}$ thick), located at the top of the sequence, in the Upper Cambrian.

X-ray diffraction studies of the eight samples were carried out using a Philips PW 1710 powder diffractometer with $\mathrm{Cu}-K \alpha$ radiation, a graphite monochromator, and automatic divergence slit. The $<2 \mu \mathrm{m}$ and $<20 \mu \mathrm{m}$ fractions were separated by sedimentation through a column of water; oriented aggregates were prepared by sedimentation on glass slides. Ethylene glycol treatment at $60-70^{\circ} \mathrm{C}$ for 3 days and heating treatment at $550^{\circ} \mathrm{C}$ for $1 \mathrm{~h}$ were performed on the oriented aggregates.

Whole-rock compositions were obtained by X-ray fluorescence (XRF) spectrometry, using a Philips PW 1040/10 spectrometer in the Centro de Instrumentación Científica (C.I.C., Granada University). Only major elements were analysed (Table 1), using glass beads, in an attempt to minimize the effect of preferential orientation of phyllosilicates. The $\mathrm{Fe}^{2+}$ was determined by volumetric titration with $\mathrm{K}_{2} \mathrm{Cr}_{2} \mathrm{O}_{7}$.

For the optical study, samples were prepared as thin-sections mounted with Canada Balsam. Thinsections were examined using optical microscopy. Only chlorite (filling mm-scale vesicles) in basic lavas was selected for the study. Chlorites from metabasalts were analysed in a four spectrometer CAMECA-CAMEBAX SX-5020 electron microprobe at the C.I.C., with $20 \mathrm{kV}, 20 \mathrm{nA}$ and a $5-8 \mu \mathrm{m}$ beam diameter as analytical conditions and with synthetic oxides as well as natural silicate minerals (albite, orthoclase and wollastonite) as standards.

Chlorites from vesicles of samples ZF-3, ZF-5, ZF-6 and ZF-8 were ion-thinned using a Gatan 600 ion mill and carbon-coated. A Philips CM-20 scanning transmission electron microscope (STEM), operating at $200 \mathrm{kV}$ with a $\mathrm{LaB}_{6}$ filament, and equipped with an ultrathin window EDX detector (C.I.C.) was used. Point-to-point resolution was $0.27 \mathrm{~nm}$. Electron diffraction patterns were obtained from selected areas (SAED) and HRTEM lattice-fringe images were obtained following the procedures suggested by Buseck et al. (1988) and Buseck (1992). The areas for phyllosilicate analysis were selected carefully on lattice-fringe images in order to define the textural position and verify the absence of contamination by other phases. Quantitative analyses were obtained only from 
TABLE 1. Geochemical analyses of the selected lava flows from the Middle-Upper Cambrian. Major elements (XRF) in wt.\%. Sample C91-25 (pelite) from López-Munguira et al. (1996) is expressed on an anhydrous basis.

\begin{tabular}{|c|c|c|c|c|c|c|c|c|c|}
\hline $\begin{array}{l}\text { Sample } \\
\text { Type } \\
\text { Depth (m) }\end{array}$ & $\begin{array}{c}\mathrm{ZF}-8 \\
\text { basalt } \\
10\end{array}$ & $\begin{array}{c}\mathrm{ZF}-7 \\
\text { basalt } \\
70\end{array}$ & $\begin{array}{c}\text { ZF-6 } \\
\text { basalt } \\
170\end{array}$ & $\begin{array}{c}\mathrm{ZF}-5 \\
\text { basalt } \\
800\end{array}$ & $\begin{array}{c}\mathrm{ZF}-4 \\
\text { basalt } \\
850\end{array}$ & $\begin{array}{c}\mathrm{ZF}-\mathrm{C} \\
\text { basalt } \\
900\end{array}$ & $\begin{array}{c}\text { ZF-3 } \\
\text { basalt } \\
950\end{array}$ & $\begin{array}{c}\mathrm{ZF}-\mathrm{O} \\
\text { basalt } \\
960\end{array}$ & $\begin{array}{c}\text { C91-25 } \\
\text { pelite } \\
200\end{array}$ \\
\hline $\mathrm{SiO}_{2}$ & 52.70 & 51.49 & 47.58 & 45.41 & 56.95 & 48.94 & 43.73 & 47.58 & 63.03 \\
\hline $\mathrm{TiO}_{2}$ & 3.93 & 3.31 & 3.95 & 4.11 & 4.23 & 3.19 & 3.69 & 4.04 & 0.98 \\
\hline $\mathrm{Al}_{2} \mathrm{O}_{3}$ & 15.15 & 14.78 & 13.29 & 13.79 & 13.89 & 18.20 & 14.03 & 13.96 & 21.40 \\
\hline $\mathrm{Fe}_{2} \mathrm{O}_{3}$ & 3.14 & 2.46 & 3.79 & 2.49 & 2.63 & 9.67 & 7.35 & 6.79 & 4.09 \\
\hline $\mathrm{FeO}$ & 8.22 & 8.97 & 10.28 & 12.44 & 9.84 & 4.34 & 5.26 & 6.88 & 2.50 \\
\hline $\mathrm{MnO}$ & 0.14 & 0.16 & 0.15 & 0.17 & 0.14 & 0.05 & 0.20 & 0.23 & 0.05 \\
\hline $\mathrm{MgO}$ & 1.42 & 1.53 & 5.86 & 4.37 & 2.71 & 2.36 & 1.88 & 4.55 & 1.71 \\
\hline $\mathrm{CaO}$ & 2.84 & 4.89 & 3.72 & 4.82 & 0.99 & 0.95 & 7.18 & 6.75 & 0.28 \\
\hline $\mathrm{Na}_{2} \mathrm{O}$ & 5.69 & 4.29 & 3.86 & 4.67 & 3.80 & 2.09 & 3.20 & 2.72 & 1.47 \\
\hline $\mathrm{K}_{2} \mathrm{O}$ & 0.64 & 0.48 & 0.12 & 0.20 & 0.21 & 3.21 & 3.29 & 1.18 & 4.39 \\
\hline $\mathrm{P}_{2} \mathrm{O}_{5}$ & 0.83 & 0.70 & 0.36 & 0.58 & 0.17 & 0.37 & 0.36 & 0.76 & 0.10 \\
\hline LOI & 4.75 & 6.29 & 6.52 & 6.23 & 4.03 & 5.34 & 9.28 & 3.29 & \\
\hline Total & 99.45 & 99.35 & 99.48 & 99.28 & 99.59 & 98.71 & 99.45 & 98.73 & 100.00 \\
\hline$[\mathrm{mg}]$ & 0.24 & 0.23 & 0.50 & 0.39 & 0.33 & 0.49 & 0.39 & 0.54 & 0.55 \\
\hline
\end{tabular}

LOI: Loss on ignition $\left(\right.$ at $950^{\circ} \mathrm{C}$ )

$[\mathrm{mg}]=\mathrm{Mg} /\left(\mathrm{Mg}+\mathrm{Fe}^{2+}\right)$ expressed as atomic $\%$.

The depths listed refer to the stratigraphic location of the samples in the column in Fig. 1.

thin edges, using a $70 \AA$ beam diameter and a $1000 \times 200 \AA$ scanning area, with the long axis oriented parallel to the phyllosilicate packets. The sample was tilted at $20^{\circ}$ toward the detector to give an X-ray take-off angle of $34^{\circ}$. Albite, biotite, spessartine, muscovite, olivine, titanite, $\mathrm{CaSO}_{4}$ and $\mathrm{MnSO}_{4}$ standards were used to obtain K-factors for the transformation of intensity ratios to concentration following Cliff and Lorimer (1975) and Champness et al. (1981). Oxygen was not measured quantitatively. Formulae were determined from atomic concentration ratios based on the number of oxygen atoms in the ideal formulae.

\section{RESULTS}

\section{Optical microscopy}

Petrographic studies of the four basaltic lava flows gave similar results. The lavas are porphyritic basalts with idiomorphic phenocrysts of plagioclase which were partially or completely chloritized. Plagioclase microlaths, opaque minerals and chlorite and quartz, as alteration products of the glass, form the groundmass. Vesicles, more abundant in the lava from the Middle-Upper Cambrian boundary (samples ZF-4, ZF-5 and ZF-6), are always filled by chlorite (Fig. 2). Partially chloritized calcite phenocrysts are abundant in the upper lava flow. In sample ZF-0, epidote is present in the groundmass and filling small veinlets.

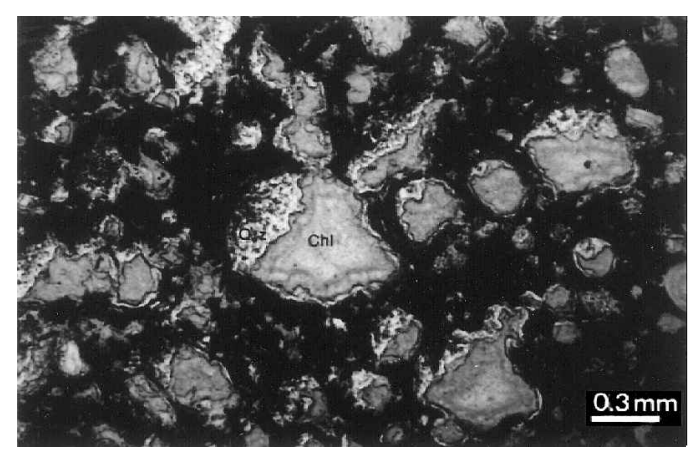

FIG. 2. Optical micrograph showing chlorite-filled vesicles of sample ZF-5. 


\section{Whole-rock X-ray diffraction}

The results of XRD qualitative mineralogical determinations are very similar in all samples (Table 2). Chlorite, plagioclase, calcite and quartz \pm mica are the main minerals. In sample $\mathrm{ZF}-0$, epidote is the major mineral and berthierine (instead of chlorite) is a major phase in sample ZF-3. Quantitatively, the mica and quartz proportions are variable, with higher proportions in samples $\mathrm{ZF}-3$ and $\mathrm{ZF}-8$ (in this latter sample, the plagioclase content is $>50 \%$ ). Mica is absent from sample ZF-6 and is only present as a trace mineral in sample ZF-5. Basal reflections of chlorite showed no changes in spacing after ethylene glycol treatment or heating at $550^{\circ} \mathrm{C}$.

\section{HRTEM}

The HRTEM study of chlorites from vesicles indicates the existence of two major types of textures. The first developed in the lower and upper lava flows (samples ZF-3 and ZF-8) and the second in the middle lava flow (samples ZF-5 and ZF-6).

In the first type (Fig. 3a), the chlorite areas comprise small crystals, 200-700 $\AA$ thick, some of which are not parallel. Some scarce mica crystals randomly distributed in relation to chlorite can be found. In sample ZF-3, frequent $7 \AA$ berthierine intercalations within the $14 \AA$ chlorite can be observed (Fig. 4). Taking into account the fact that XRD analyses give the whole-rock mineral composition and the HRTEM study was carried out on just the vesicles, the disparity between the two techniques (mostly berthierine in XRD vs. mostly chlorite in HRTEM) is easily explained. Therefore, all the conclusions developed in subsequent sections have been obtained using chlorite from vesicles exclusively.

Chlorites occur as variable stacking sequences coexisting in the same sample, from semi-random sequences up to long-period stacking sequences of 5, 6, 7 and 8 layers, with sequences of 5 (Fig. 3b) and 6 (Fig. 3c) layers being the most frequent.

In the second type, chlorite crystals form a crossed pattern without preferential orientation (Fig 5a). Defect-free packets ranging in size from 100 to $>500 \AA$ thick are frequently separated by low-angle crystal boundaries. In sample ZF-5, rare $10 \AA$ layers are observed. The most frequent long-period stacking sequence is three layers (Fig. 5b), but sequences of four and one layers (Fig. 5c) are also present; semi-random sequences have also been found.

\section{Chemical composition}

Mean EMPA chlorite analyses from the samples belonging to the four basaltic lava flows are shown in Table 3. Table 4 presents the results of the chlorite chemical analysis using AEM.

In Fig. 6, a close relationship between the various chemical components of chlorites is illustrated. A positive correlation has been found between $\mathrm{Si}-\mathrm{Mg}$, $\mathrm{Al}^{\mathrm{IV}}-\mathrm{Al}^{\mathrm{VI}}$, and $\mathrm{Al}^{\mathrm{IV}}-\mathrm{Fe} / \mathrm{Fe}+\mathrm{Mg}$. The $\mathrm{Mg}$ is negatively correlated with $\mathrm{Al}$ and $\mathrm{Fe}$. Total $\mathrm{Al}$ and $\mathrm{Si}$ also present a negative correlation. These relationships are evident in all the diagrams represented in Fig. 6 if the epidote-bearing sample, ZF-0, is excluded. The $\mathrm{Mg}$ content for this sample is clearly anomalous in relation to the others and

TABLE 2. Mineral composition determined by XRD.

\begin{tabular}{|c|c|c|c|c|c|c|c|c|}
\hline Sample & ZF-8 & ZF-7 & ZF-6 & ZF-5 & ZF-4 & ZF-C & ZF-3 & ZF-O \\
\hline Quartz & $\mathrm{x}$ & $\mathrm{x}$ & $\mathrm{x}$ & $\mathrm{x}$ & $\mathrm{x}$ & $\mathrm{x}$ & $\mathrm{x}$ & $\mathrm{x}$ \\
\hline Albite & $\mathrm{x}$ & $\mathrm{x}$ & $\mathrm{x}$ & $\mathrm{x}$ & $\mathrm{x}$ & $\mathrm{x}$ & $\mathrm{x}$ & $\mathrm{x}$ \\
\hline Mica & & $\mathrm{i}$ & & & & $\mathrm{i}$ & $\mathrm{x}$ & \\
\hline Chlorite & $\mathrm{x}$ & $\mathrm{x}$ & $\mathrm{x}$ & $\mathrm{x}$ & $\mathrm{x}$ & $\mathrm{x}$ & $\mathrm{i}$ & $\mathrm{x}$ \\
\hline Berthierine & & & & & & & $\mathrm{x}$ & \\
\hline Calcite & $\mathrm{x}$ & $\mathrm{x}$ & $\mathrm{x}$ & $\mathrm{x}$ & $\mathrm{i}$ & $\mathrm{i}$ & $\mathrm{x}$ & \\
\hline Epidote & & & & & & & & $\mathrm{x}$ \\
\hline Hematite & $\mathrm{i}$ & $\mathrm{i}$ & & & & & $\mathrm{x}$ & \\
\hline
\end{tabular}

$\mathrm{x}$ : major minerals

i: trace minerals 

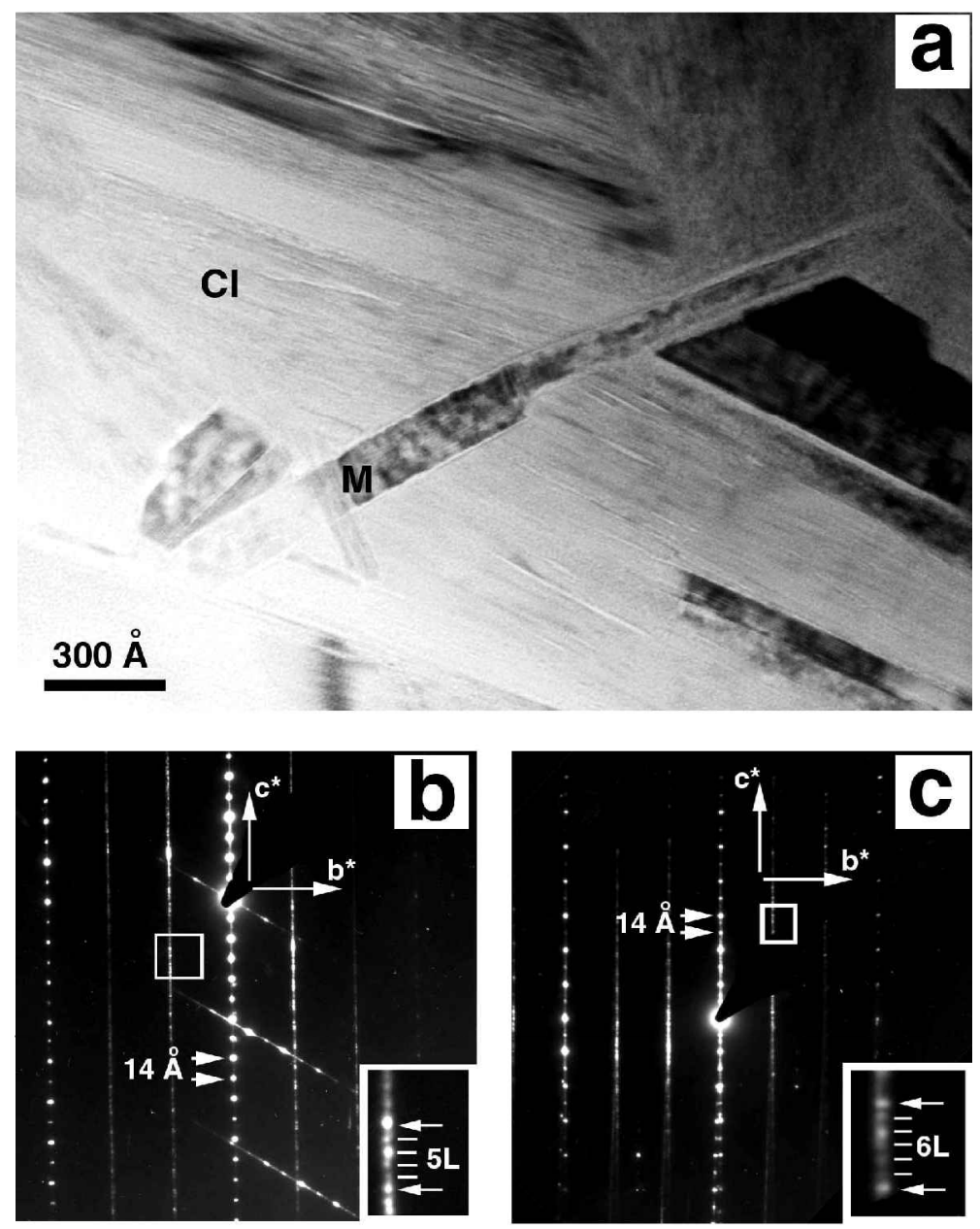

FIG. 3. (a) Typical texture of lava vesicles from the upper and lower flows (sample ZF-3). (b) SAED patterns along [100] of the chlorite showing 5-layer stacking (sample ZF-8). (c) SAED patterns along [100] of the chlorite showing 6-layer stacking (sample ZF-8). Cl: chlorite; M: mica.

therefore all the diagrams containing this element show ZF-0 plotting outside of the general trend. The Fe content is generally greater than that of $\mathrm{Mg}$, allowing the classification of these chlorites as chamosite. Sample ZF-6 can be considered as intermediate between clinochlore and chamosite, and $\mathrm{ZF}-0$ as clinochlore.

Figure 7 is a comparison between chemical compositions obtained by EMPA (Table 3) and those determined by AEM (Table 4). The Mg and total Al present very similar results in both cases. The Si content is systematically less in AEM, with a difference of $\sim 0.15$ a.p.f.u. The Fe is systematically overestimated by AEM at $\sim 0.15$ a.p.f.u.
These results produce a systematically greater $\Sigma$ oct in AEM of $~ 0.1$ a.p.f.u.

\section{DISCUSSION}

The question of the quality of AEM data

The accuracy of chemical data obtained by EDX in transmission electron microscopy is a controversial matter (e.g. Warren and Ransom, 1992). In recent years, such data have been used widely in mineralogical literature, particularly in very lowgrade metamorphic and diagenetic-condition studies. Nevertheless, their ability to produce 


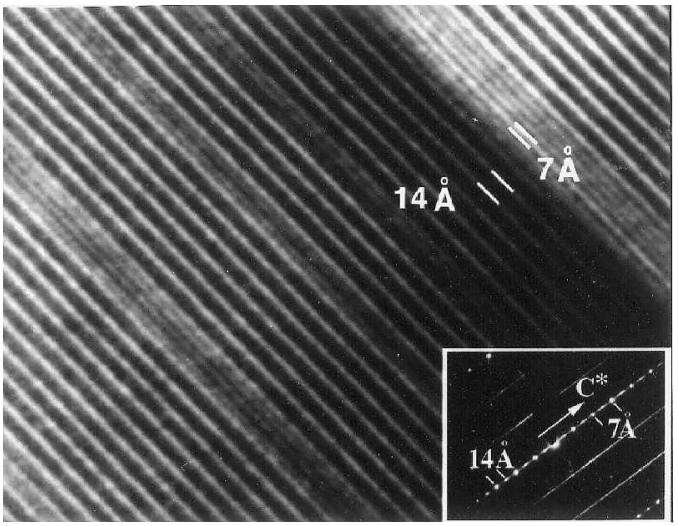

FIG. 4. Lattice-fringe image and SAED (inset) of sample ZF-3 showing berthierine layers interleaved with chlorite. useful mineral formulae has been questioned (Merriman \& Peacor, 1999, and references therein).

The XRD and lattice-fringe images have allowed us to establish that the chlorites in the basic rocks of the Alconera Formation are free of smectite and other dioctahedral phyllosilicate contamination even at sub-optical and sub-microprobe resolution scales. Therefore, the EMPA data obtained (Table 3) represent their genuine composition. During the TEM study, AEM analyses were obtained (Table 4) which has given us an opportunity to compare the two sources of data (Fig. 7) in order to evaluate the quality of the latter.

Random errors can be noted by the higher standard deviations of AEM data than their equivalent EMPA ones (Fig. 7). In addition, significant systematic errors are detected for $\mathrm{Si}$

TABlE 3. Mean values from microprobe analyses of chlorites from basic lavas, with standard deviation in parentheses. Atoms per formula unit calculated on the basis of 14 oxygens.

\begin{tabular}{|c|c|c|c|c|c|c|c|c|}
\hline $\begin{array}{l}\text { Sample } \\
\text { anal. no. }\end{array}$ & $\begin{array}{c}* \text { ZF-8 } \\
10\end{array}$ & $\begin{array}{c}\text { ZF-7 } \\
17\end{array}$ & $\begin{array}{c}* \text { ZF-6 } \\
8\end{array}$ & $\begin{array}{c}* \text { ZF-5 } \\
9\end{array}$ & $\begin{array}{c}\text { ZF-4 } \\
12\end{array}$ & $\begin{array}{c}\text { ZF-C } \\
12\end{array}$ & $\begin{array}{c}* \mathrm{ZF}-3 \\
5\end{array}$ & $\begin{array}{c}\text { ZF-0 } \\
18\end{array}$ \\
\hline $\mathrm{SiO}_{2}$ & $24.4(39)$ & $22.91(45)$ & $29.67(80)$ & $27.41(57)$ & $25.28(66)$ & $24.84(91)$ & $24.73(41)$ & $27.84(76)$ \\
\hline $\mathrm{TiO}_{2}$ & $0.01(01)$ & $0.04(06)$ & $0.03(02)$ & $0.04(02)$ & $0.08(06)$ & $0.03(02)$ & $0.03(02)$ & $0.04(03)$ \\
\hline $\mathrm{Al}_{2} \mathrm{O}_{3}$ & $22.34(52)$ & $21.39(29)$ & $15.24(52)$ & $17.54(78)$ & $18.42(61)$ & 19.61(1.07) & $20.23(30)$ & $17.73(47)$ \\
\hline $\mathrm{MgO}$ & $4.96(28)$ & $5.19(25)$ & $15.18(73)$ & $11.56(74)$ & $8.72(46)$ & $8.28(99)$ & $6.84(78)$ & $18.64(1.31)$ \\
\hline $\mathrm{FeO}$ & $36.45(37)$ & $36.69(63)$ & $27.24(68)$ & $31.61(61)$ & $33.48(50)$ & $32.95(81)$ & $36.61(1.01)$ & $21.65(1.43)$ \\
\hline $\mathrm{MnO}$ & $0.06(02)$ & $0.07(02)$ & $0.23(03)$ & $0.29(03)$ & $0.32(03)$ & $0.03(01)$ & $0.03(02)$ & $0.26(06)$ \\
\hline $\mathrm{CaO}$ & $0.01(01)$ & $0.06(07)$ & $0.11(05)$ & $0.13(04)$ & $0.17(05)$ & $0.16(12)$ & $0.07(09)$ & $0.14(23)$ \\
\hline $\mathrm{Na}_{2} \mathrm{O}$ & $0.03(03)$ & $0.02(01)$ & $0.02(01)$ & $0.03(02)$ & $0.04(09)$ & $0.11(10)$ & $0.01(02)$ & $0.06(06)$ \\
\hline $\mathrm{K}_{2} \mathrm{O}$ & $0.02(01)$ & $0.05(11)$ & $0.01(01)$ & $0.02(01)$ & $0.03(01)$ & $0.10(14)$ & $0.03(03)$ & $0.02(02)$ \\
\hline Total & $88.27(84)$ & $86.43(50)$ & $88.34(1.13)$ & $88.62(72)$ & $86.54(77)$ & $86.13(83)$ & $88.61(62)$ & $86.38(80)$ \\
\hline \multicolumn{9}{|c|}{ Structural formulae on the basis of 14 oxygens } \\
\hline $\mathrm{Si}$ & $2.70(02)$ & $2.63(04)$ & $3.13(05)$ & $2.95(05)$ & $2.84(05)$ & $2.79(12)$ & $2.74(03)$ & $2.93(05)$ \\
\hline $\mathrm{Al}^{\mathrm{IV}}$ & $1.30(02)$ & $1.38(04)$ & $0.87(05)$ & $1.05(05)$ & $1.16(05)$ & $1.21(12)$ & $1.26(03)$ & $1.08(05)$ \\
\hline $\mathrm{Al}^{\mathrm{VI}}$ & $1.62(04)$ & $1.51(04)$ & $1.03(04)$ & $1.18(06)$ & $1.28(05)$ & $1.39(08)$ & $1.39(04)$ & $1.12(04)$ \\
\hline $\mathrm{Mg}$ & $0.82(05)$ & $0.89(04)$ & $2.39(09)$ & $1.86(12)$ & $1.46(08)$ & $1.39(16)$ & $1.13(13)$ & $2.92(18)$ \\
\hline $\mathrm{Fe}$ & $3.38(04)$ & $3.52(08)$ & $2.46(08)$ & $2.85(06)$ & $3.15(07)$ & $3.10(08)$ & $3.40(10)$ & $1.91(14)$ \\
\hline $\mathrm{Ti}$ & $0.00(00)$ & $0.00(00)$ & $0.00(00)$ & $0.00(00)$ & $0.01(005)$ & $0.00(00)$ & $0.00(00)$ & $0.00(00)$ \\
\hline $\mathrm{Mn}$ & $0.01(005)$ & $0.01(005)$ & $0.02(005)$ & $0.03(005)$ & $0.03(005)$ & $0.00(00)$ & $0.00(00)$ & $0.02(01)$ \\
\hline$\Sigma$ Oct & $5.83(03)$ & $5.93(04)$ & $5.90(03)$ & $5.91(04)$ & $5.93(04)$ & $5.88(10)$ & $5.92(03)$ & $5.97(05)$ \\
\hline $\mathrm{K}$ & $0.01(00)$ & $0.01(02)$ & $0.00(00)$ & $0.00(00)$ & $0.00(00)$ & $0.01(02)$ & $0.01(01)$ & $0.00(00)$ \\
\hline $\mathrm{Na}$ & $0.01(005)$ & $0.00(00)$ & $0.00(00)$ & $0.01(005)$ & $0.01(02)$ & $0.02(02)$ & $0.00(00)$ & $0.01(01)$ \\
\hline $\mathrm{Ca}$ & $0.01(005)$ & $0.01(01)$ & $0.01(01)$ & $0.02(01)$ & $0.02(01)$ & $0.02(02)$ & $0.01(01)$ & $0.01(03)$ \\
\hline F/FM & 0.80 & 0.80 & 0.5 & 0.6 & 0.68 & 0.69 & 0.75 & 0.39 \\
\hline $\mathrm{T} 1$ & 350 & 381 & 215 & 275 & 312 & 327 & 340 & 285 \\
\hline $\mathrm{T} 2$ & 145 & 173 & 132 & 147 & 153 & 165 & 155 & 251 \\
\hline$X_{\mathrm{c}}$ & 0.81 & 0.94 & 0.89 & 0.90 & 0.94 & 0.89 & 0.91 & 0.98 \\
\hline
\end{tabular}

T1: Temperature calculated using the Cathelineau (1988) geothermometer

T2: Temperature corrected using the F/FM factor (Xie et al., 1997)

$X_{\mathrm{c}}=$ chlorite component

* Data from López-Munguira et al. (1998) 

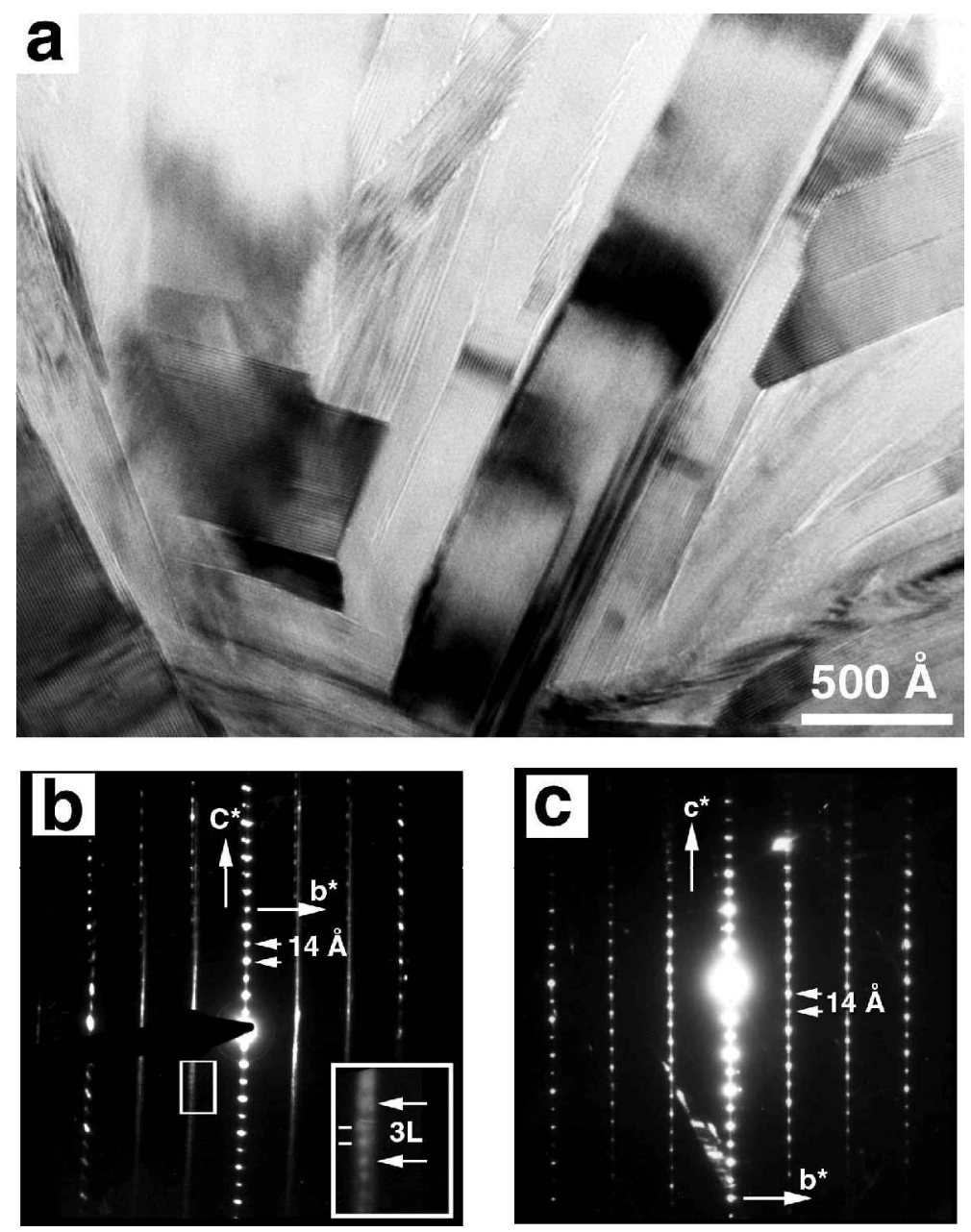

FIG. 5. (a) Lattice-fringe image showing the typical chlorite texture from vesicles of the middle lava flow. No other phases are visible. (b) SAED patterns along [100] of the chlorite showing 3-layer stacking. (c) SAED patterns along [100] of the chlorite showing 1-layer stacking. Sample ZF-5.

and $\mathrm{Fe}$, which also produce a systematic error in the Soctahedral cations. These errors can be roughly evaluated at $\sim 0.15$ a.p.f.u., which represents $5-10 \%$ of the total quantity of $\mathrm{Si}$ or Fe. This is very similar or even less than the expected accuracy of the thinfilm approximation by Cliff and Lorimer (1975) and therefore a predictable result. Moreover, the differences between EMPA and AEM data may be, in part, a consequence of small variations in composition between two areas analysed of the same rock. Sample-preparation requirements demand the use of two different thin-sections (see 'Methods') and very low-grade rocks are affected by a lack of chemical equilibrium (Merriman \& Peacor, 1999). In fact, the ranges of EMPA compositions are also significant and may explain about half of the AEM equivalent ranges (Fig. 7).

In conclusion, AEM is able to produce mineral formulae within a limited range of errors, which, for major elements can be expected to be $<10 \%$, or even better for some elements. No petrogenetic conclusions can be made based on these data if better than $10 \%$ accuracy is necessary because this is the predicted and expected limit of the method. The controversy about the AEM data may be a result of the use of very different approaches and 
TABLE 4. AEM data for chlorites normalized to $\mathrm{O}_{10}(\mathrm{OH})_{8}$.

\begin{tabular}{|c|c|c|c|c|c|c|c|c|c|c|c|}
\hline ZF-3 & $\mathrm{Si}$ & ${ }^{\mathrm{IV}} \mathrm{Al}$ & ${ }^{\mathrm{VI}} \mathrm{Al}$ & $\mathrm{Mg}$ & $\mathrm{Fe}$ & $\mathrm{Ti}$ & $\mathrm{Mn}$ & $\Sigma$ Oct & $\mathrm{K}$ & $\mathrm{Na}$ & $\mathrm{Ca}$ \\
\hline $\mathrm{c} 1$ & 2.57 & 1.43 & 1.16 & 1.29 & 3.69 & 0.00 & 0.00 & 6.14 & 0.00 & 0.00 & 0.00 \\
\hline c2 & 2.57 & 1.43 & 1.10 & 1.14 & 3.92 & 0.00 & 0.00 & 6.16 & 0.00 & 0.00 & 0.00 \\
\hline c4 & 2.70 & 1.30 & 1.33 & 1.13 & 3.37 & 0.00 & 0.02 & 5.85 & 0.00 & 0.00 & 0.00 \\
\hline c6 & 2.45 & 1.55 & 1.17 & 1.13 & 3.88 & 0.00 & 0.00 & 6.18 & 0.00 & 0.00 & 0.00 \\
\hline c7 & 2.64 & 1.36 & 1.14 & 1.39 & 3.54 & 0.00 & 0.00 & 6.07 & 0.00 & 0.00 & 0.03 \\
\hline c8 & 2.49 & 1.51 & 1.15 & 1.41 & 3.61 & 0.00 & 0.00 & 6.17 & 0.00 & 0.00 & 0.00 \\
\hline 1 & 2.53 & 1.47 & 1.02 & 1.34 & 3.68 & 0.09 & 0.00 & 6.13 & 0.00 & 0.00 & 0.03 \\
\hline 2 & 2.69 & 1.31 & 1.24 & 1.27 & 3.47 & 0.00 & 0.00 & 5.98 & 0.00 & 0.00 & 0.05 \\
\hline 3 & 2.83 & 1.17 & 1.43 & 1.17 & 3.09 & 0.02 & 0.01 & 5.72 & 0.14 & 0.00 & 0.05 \\
\hline 4 & 2.53 & 1.47 & 1.15 & 1.17 & 3.80 & 0.00 & 0.00 & 6.12 & 0.01 & 0.00 & 0.04 \\
\hline 5 & 2.47 & 1.53 & 1.17 & 1.36 & 3.65 & 0.00 & 0.00 & 6.18 & 0.00 & 0.00 & 0.00 \\
\hline 6 & 2.59 & 1.41 & 1.23 & 1.21 & 3.64 & 0.00 & 0.00 & 6.08 & 0.00 & 0.00 & 0.00 \\
\hline 7 & 2.59 & 1.41 & 1.19 & 1.29 & 3.56 & 0.00 & 0.00 & 6.04 & 0.02 & 0.00 & 0.05 \\
\hline $\mathrm{m}$ & 2.59 & 1.41 & 1.19 & 1.25 & 3.61 & 0.01 & 0.00 & 6.06 & 0.01 & 0.00 & 0.02 \\
\hline std & 0.11 & 0.11 & 0.10 & 0.10 & 0.22 & 0.03 & 0.01 & 0.14 & 0.04 & 0.00 & 0.02 \\
\hline \multicolumn{12}{|l|}{ ZF-5 } \\
\hline $\mathrm{c} 1$ & 2.69 & 1.31 & 1.13 & 1.70 & 3.21 & 0.00 & 0.04 & 6.08 & 0.24 & 0.00 & 0.01 \\
\hline c2 & 2.82 & 1.18 & 1.06 & 1.98 & 2.96 & 0.00 & 0.03 & 6.03 & 0.00 & 0.00 & 0.00 \\
\hline c3 & 2.82 & 1.18 & 1.13 & 1.76 & 3.11 & 0.00 & 0.03 & 6.03 & 0.00 & 0.00 & 0.00 \\
\hline c4 & 2.79 & 1.21 & 0.97 & 1.99 & 3.14 & 0.00 & 0.02 & 6.12 & 0.00 & 0.00 & 0.00 \\
\hline c5 & 2.72 & 1.28 & 1.15 & 1.93 & 2.96 & 0.00 & 0.03 & 6.07 & 0.00 & 0.00 & 0.00 \\
\hline c6 & 2.72 & 1.28 & 1.18 & 1.79 & 3.07 & 0.00 & 0.02 & 6.06 & 0.00 & 0.00 & 0.00 \\
\hline c7 & 2.95 & 1.05 & 1.18 & 1.82 & 2.88 & 0.00 & 0.04 & 5.92 & 0.00 & 0.00 & 0.00 \\
\hline 4 & 2.91 & 1.09 & 1.18 & 1.73 & 2.98 & 0.00 & 0.01 & 5.90 & 0.00 & 0.11 & 0.00 \\
\hline 5 & 2.87 & 1.13 & 1.06 & 1.87 & 3.05 & 0.00 & 0.04 & 6.02 & 0.00 & 0.00 & 0.00 \\
\hline 6 & 3.09 & 0.91 & 1.40 & 1.54 & 2.69 & 0.00 & 0.02 & 5.65 & 0.00 & 0.21 & 0.00 \\
\hline 7 & 2.79 & 1.21 & 1.10 & 1.69 & 3.21 & 0.00 & 0.03 & 6.03 & 0.00 & 0.00 & 0.03 \\
\hline 8 & 2.76 & 1.24 & 0.98 & 1.95 & 3.16 & 0.00 & 0.00 & 6.09 & 0.00 & 0.00 & 0.03 \\
\hline $\mathrm{m}$ & 2.83 & 1.17 & 1.13 & 1.81 & 3.04 & 0.00 & 0.03 & 6.00 & 0.02 & 0.03 & 0.01 \\
\hline std & 0.11 & 0.11 & 0.11 & 0.14 & 0.15 & 0.00 & 0.01 & 0.13 & 0.07 & 0.07 & 0.01 \\
\hline \multicolumn{12}{|l|}{ ZF-6 } \\
\hline 1 & 2.92 & 1.08 & 1.11 & 2.10 & 2.78 & 0.00 & 0.00 & 5.99 & 0.00 & 0.00 & 0.00 \\
\hline 3 & 3.06 & 0.94 & 0.94 & 2.43 & 2.62 & 0.00 & 0.02 & 6.01 & 0.00 & 0.00 & 0.00 \\
\hline 4 & 2.66 & 1.34 & 1.14 & 2.15 & 2.70 & 0.00 & 0.01 & 6.00 & 0.00 & 0.00 & 0.10 \\
\hline 5 & 2.71 & 1.29 & 1.20 & 2.08 & 2.66 & 0.00 & 0.02 & 5.96 & 0.00 & 0.00 & 0.09 \\
\hline 6 & 2.73 & 1.27 & 1.13 & 2.12 & 2.68 & 0.00 & 0.03 & 5.96 & 0.00 & 0.00 & 0.11 \\
\hline $\mathrm{m}$ & 2.82 & 1.18 & 1.10 & 2.18 & 2.69 & 0.00 & 0.02 & 5.98 & 0.00 & 0.00 & 0.06 \\
\hline std & 0.17 & 0.17 & 0.10 & 0.14 & 0.06 & 0.00 & 0.01 & 0.02 & 0.00 & 0.00 & 0.06 \\
\hline \multicolumn{12}{|l|}{ ZF-8 } \\
\hline $\mathrm{c} 1$ & 2.52 & 1.48 & 1.34 & 1.00 & 3.72 & 0.00 & 0.00 & 6.06 & 0.00 & 0.00 & 0.00 \\
\hline c2 & 2.68 & 1.32 & 1.49 & 1.01 & 3.41 & 0.00 & 0.00 & 5.91 & 0.00 & 0.00 & 0.00 \\
\hline c3 & 2.45 & 1.55 & 1.35 & 1.03 & 3.71 & 0.00 & 0.00 & 6.09 & 0.00 & 0.00 & 0.00 \\
\hline c4 & 2.64 & 1.36 & 1.47 & 0.92 & 3.55 & 0.00 & 0.00 & 5.94 & 0.00 & 0.00 & 0.00 \\
\hline c5 & 2.81 & 1.19 & 1.62 & 0.95 & 3.16 & 0.00 & 0.00 & 5.73 & 0.09 & 0.00 & 0.03 \\
\hline c6 & 2.50 & 1.50 & 1.43 & 0.92 & 3.68 & 0.00 & 0.00 & 6.03 & 0.00 & 0.00 & 0.00 \\
\hline c7 & 2.58 & 1.42 & 1.39 & 0.94 & 3.69 & 0.00 & 0.00 & 6.02 & 0.00 & 0.00 & 0.00 \\
\hline c8 & 2.52 & 1.48 & 1.26 & 0.91 & 3.93 & 0.00 & 0.00 & 6.10 & 0.00 & 0.00 & 0.00 \\
\hline 1 & 2.74 & 1.26 & 1.43 & 1.12 & 3.23 & 0.06 & 0.00 & 5.84 & 0.00 & 0.00 & 0.00 \\
\hline 2 & 2.62 & 1.38 & 1.51 & 0.87 & 3.43 & 0.06 & 0.00 & 5.87 & 0.00 & 0.00 & 0.00 \\
\hline 3 & 2.78 & 1.22 & 1.33 & 0.99 & 3.62 & 0.00 & 0.00 & 5.94 & 0.00 & 0.00 & 0.00 \\
\hline 4 & 2.67 & 1.33 & 1.58 & 0.94 & 3.35 & 0.00 & 0.00 & 5.87 & 0.00 & 0.00 & 0.00 \\
\hline 5 & 2.62 & 1.38 & 1.44 & 0.96 & 3.38 & 0.00 & 0.00 & 5.78 & 0.00 & 0.36 & 0.00 \\
\hline 6 & 2.64 & 1.36 & 1.22 & 0.96 & 3.73 & 0.06 & 0.00 & 5.97 & 0.00 & 0.00 & 0.00 \\
\hline $\mathrm{m}$ & 2.63 & 1.37 & 1.42 & 0.97 & 3.54 & 0.01 & 0.00 & 5.94 & 0.01 & 0.03 & 0.00 \\
\hline std & 0.11 & 0.11 & 0.11 & 0.06 & 0.22 & 0.03 & 0.00 & 0.11 & 0.02 & 0.10 & 0.01 \\
\hline
\end{tabular}

m: average; std: standard deviation 

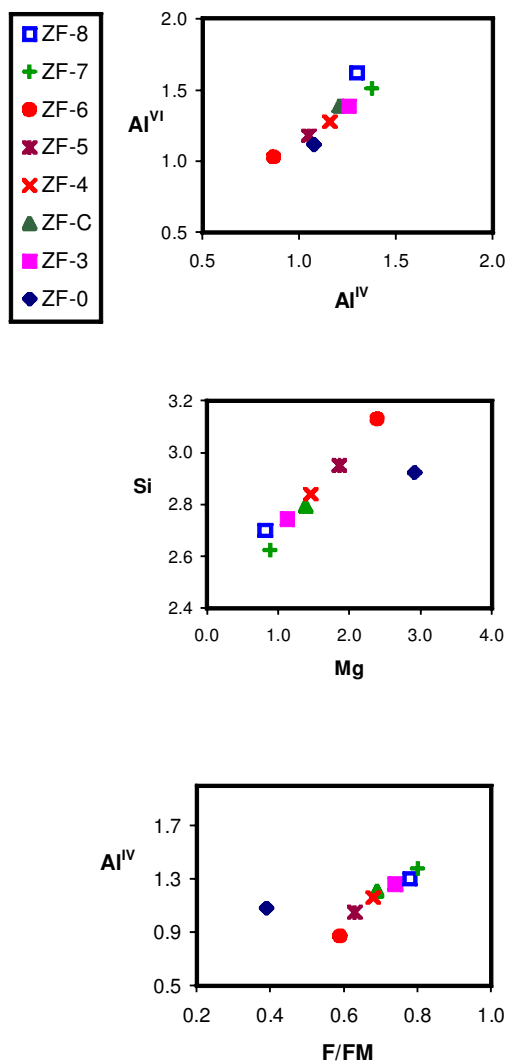
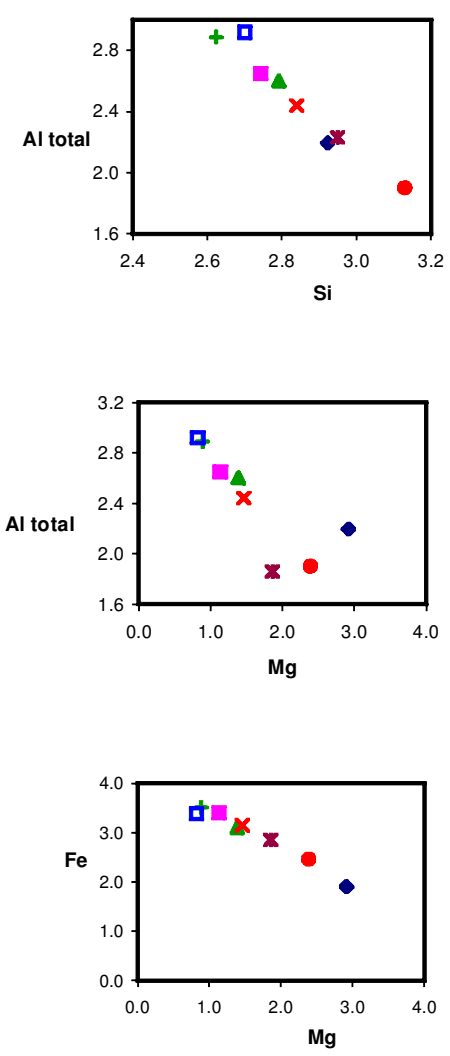

FIG. 6. Compositional diagrams of chlorites analysed by EMPA. Cations expressed in a.p.f.u.

technical conditions in different laboratories. The thin-film approximation is very sensitive to minor technical details. The data in Table 4 were obtained in STEM mode, using specific standards and within an upper limit for the maximum counts to guarantee the thin character; a low-background goniometer and top-hat ultra-thick condenser aperture were employed. Any deviation from these specific technical conditions could be responsible for poorer quality AEM results than those discussed here. A calibration of AEM analyses between different laboratories is highly recommended by the present authors.

\section{Chemical composition of chlorites and metamorphic grade}

The metamorphic grade for the Middle-Upper Cambrian pelitic rock, in which the basaltic lava flows are intercalated, was studied by LópezMunguira et al. (1998) using the IC parameter and confirmed by measurements on lattice-fringe images by López-Munguira \& Nieto (2000). According to these authors, this part of the sequence reflects very low-grade (diagenetic) metamorphic conditions ( $\mathrm{IC}=0.50 \pm 0.07 ; \mathbf{b}=$ $8.997 \pm 0.005)$. Nevertheless, the 'empirical geothermometer' of Cathelineau (1988) applied to the chlorites from the basic rocks intercalated in this sequence produces temperatures greater than those expected from these diagenetic conditions (Table 3). In addition, the temperatures obtained are affected by high scattering and do not evolve logically from the bottom to the top of the sequence. This could be explained if we consider that Cathelineau's geothermometer, as originally defined, does not consider the control of the wholerock composition. So, if we apply the correction factor proposed by Xie et al. (1997), taking into account the F/FM relationship from the chlorite, which depends mainly on the whole-rock composition, lower temperatures $\left(<200^{\circ} \mathrm{C}\right)$ are obtained 

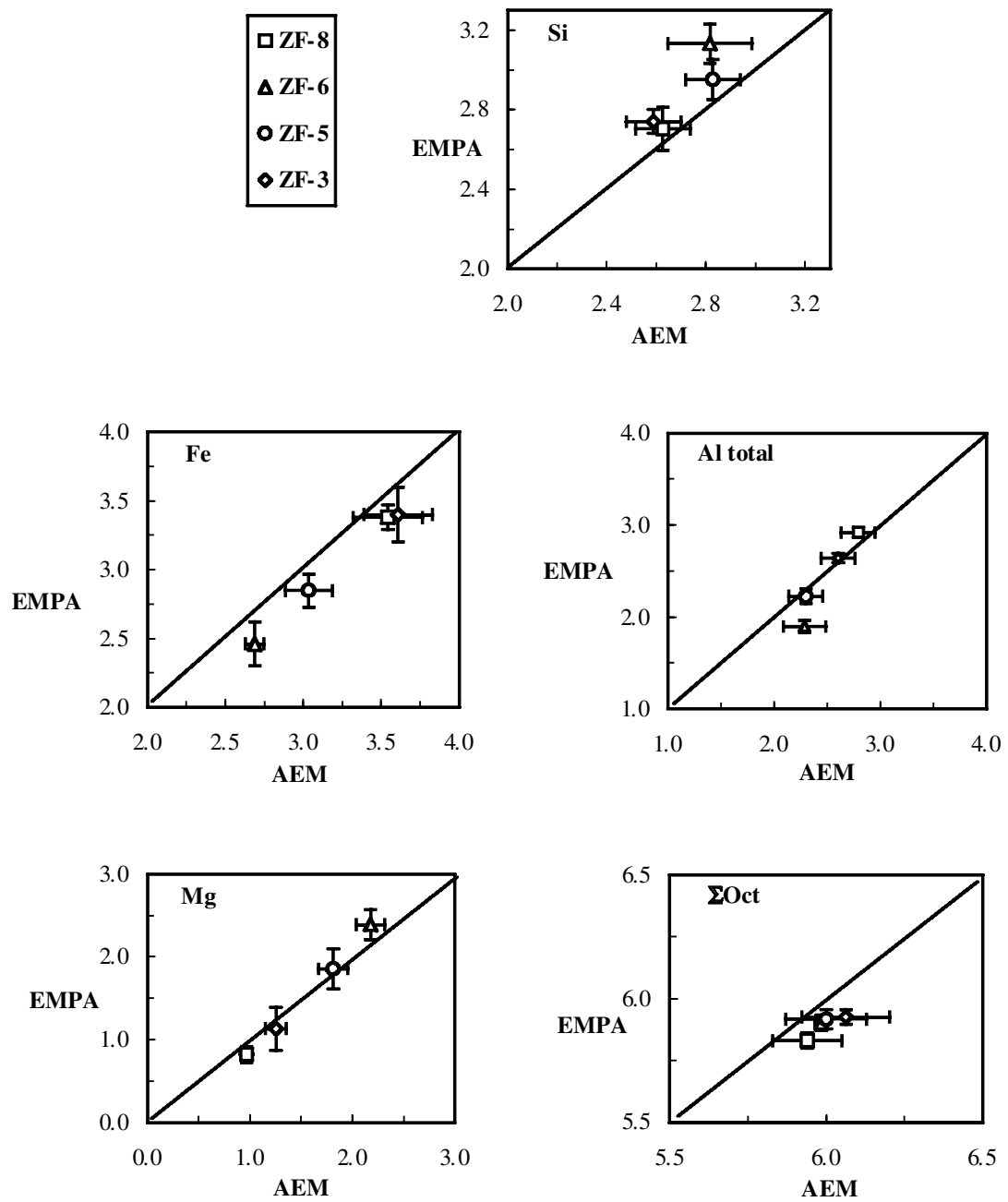

Fig. 7. Mean value and standard deviation projection of analytical electron microscopy (AEM) vs. electron microprobe analysis (EMPA) data for chlorites. Cations expresse d in a.p.f.u. Lines show the ideal 1:1 correlation .

(Table 3). These values are closer to those expected for the established diagenetic conditions. Moreover, the $\mathrm{F} / \mathrm{FM}$ chlorite ratio is too high and can influence the application of any empirical geothermometer.

The calculations of the $X_{\mathrm{c}}$ parameter obtained from microprobe analyses range from 0.81 to 0.98 in these chlorites (Table 3). This parameter is an empirical quantification of the proportion of smectite layers in the structure of the mafic phyllosilicate (values of $X_{\mathrm{c}}=1$ indicate pure chlorite and $X_{\mathrm{c}}=0$ pure smectite, Bettison \& Schiffman, 1988). Nevertheless, ethylene-glycol treatment before XRD indicates that the chlorites are completely free of any smectite layers. This was confirmed by the HRTEM study (Figs 3, 4 and 5), where no smectite layers were seen to be intercalated in the chlorite structure. If present, the quantity of these smectites would not be enough to justify the variation of the $X_{\mathrm{c}}$ values in the calculated range. This disparity can be explained if we consider that the $X_{\mathrm{c}}$ parameter calculation is based on the asumption that the true 6 $\Sigma$ octahedral cations in pure chlorite are negligible with respect to the $6-\Sigma$ octahedral cation values produced by smectite contamination. Based on lattice-fringe images, we can confirm that the real $X_{\mathrm{c}}$ is 1 in all cases, and the $X_{\mathrm{c}}$ values of slightly $<1$ 
obtained are an artefact: $\Sigma$ octahedral cations in pure chlorite can be slightly $<6$ as a result of the AM vector (dioctahedral substitution), as defined by Laird (1988).

According to the results obtained in this work, the chemical composition, textural relationships and stacking sequences of chlorites are independent of the depth of the sequence and, consequently, of the metamorphic grade. If we assume that metamorphic temperature increases with depth, no influence of temperature can be deduced in the studied
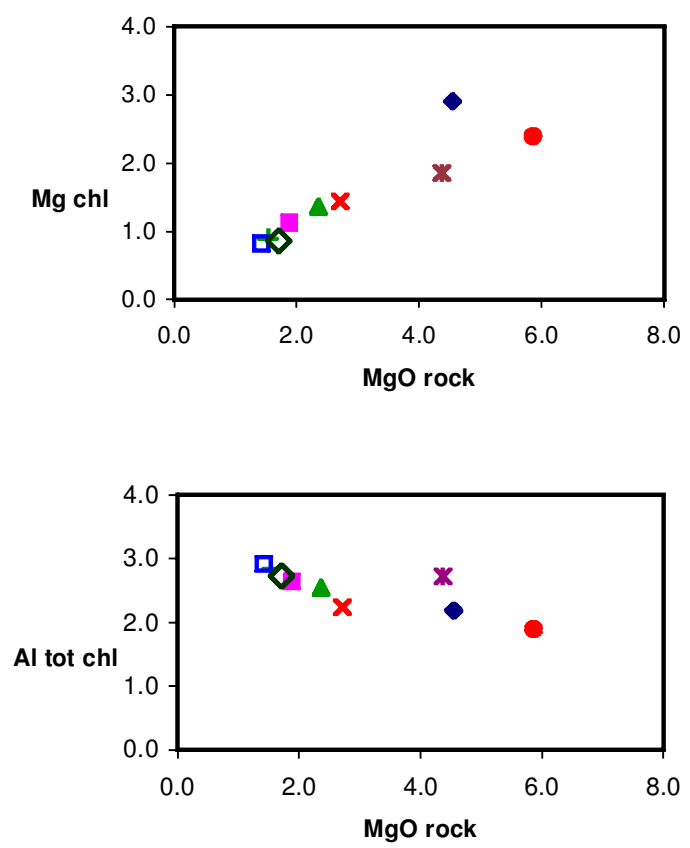

sequence: Lower and Upper samples (ZF-3 and ZF-8, respectively) have the same textural relationships and the same chemical compositions; those of the intermediate samples (ZF-5 and ZF-6) are different. The variable stacking sequences and presence of semi-random polytypes could indicate that equilibrium conditions in these rocks were not achieved.

Some diagrams were plotted with the aim of determining the influence of the whole-rock composition on the chlorite chemistry (Fig. 8). As
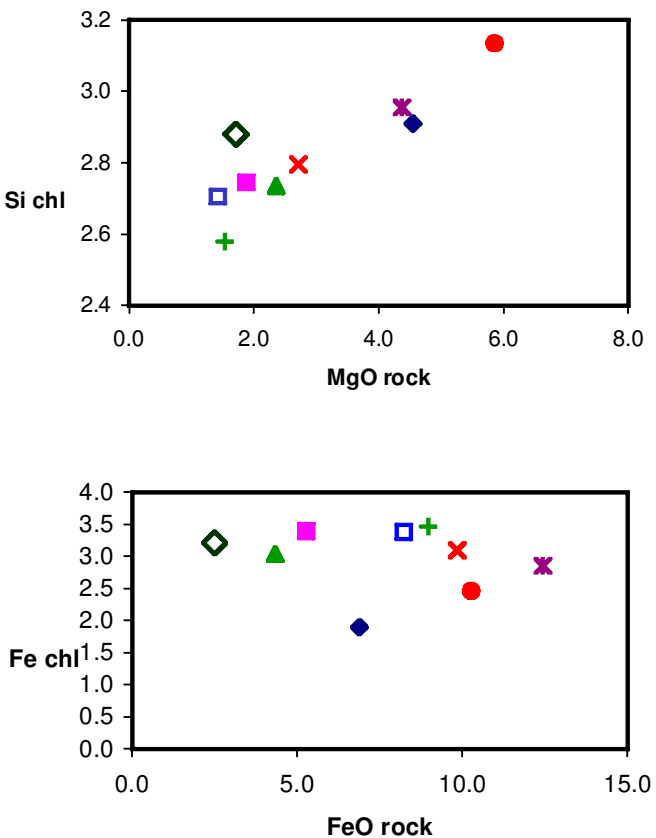

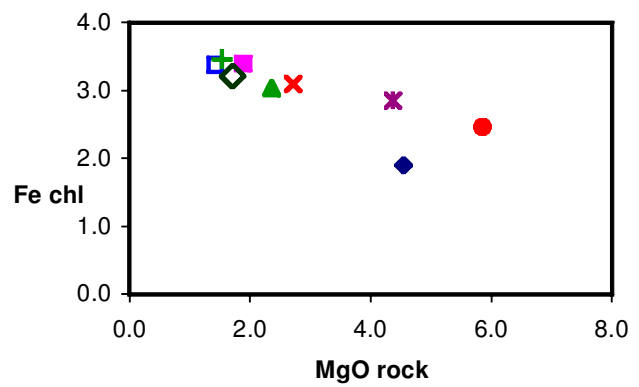

\begin{tabular}{|l|}
\hline $\mathrm{ZF}-8$ \\
$+\mathrm{ZF}-7$ \\
$-\mathrm{ZF}-6$ \\
$\times \mathrm{ZF}-5$ \\
$\times \mathrm{ZF}-4$ \\
$\Delta \mathrm{ZF}-\mathrm{C}$ \\
$\square \mathrm{ZF}-3$ \\
$-\mathrm{ZF}-0$ \\
$\diamond \mathrm{C} 91-25$ \\
\hline
\end{tabular}

FIG. 8. Projection of the whole-rock composition vs. chlorite chemical mean-value data (EMPA, Table 3). For all diagrams, the composition of the rocks is expressed in wt.\% and the composition of the chlorites in a.p.f.u., calculated to 14 oxygens. Pelitic sample C91-25 has also been plotted for comparison. 
Xie et al. (1997) showed, a good correlation between the whole-rock $\mathrm{MgO}$ content and $\mathrm{Mg}, \mathrm{Al}$, $\mathrm{Si}$ and $\mathrm{Fe}$ chlorite contents is evident. No clear relationships can be deduced from the whole-rock $\mathrm{FeO}$ and the Fe-chlorite content. In Fig. 8, the chemical compositions of a selected Middle-Upper Cambrian pelitic sample (sample C91-25, see Fig. 1) and the chemistry of chlorites from this metapelite (see Table 2, in López-Munguira \& Nieto, 2000) were plotted. There is a notable similarity between the chlorite composition from this metapelite and the chlorite composition from the lower MgO-bearing basalts. The chemical composition of the metapelite is logically very different from those of the basaltic rocks (see Table 1) and $\mathrm{MgO}$ has the only value that is of the same order as the $\mathrm{MgO}$ values of the lower $\mathrm{MgO}$ basalts (e.g. samples ZF-3, ZF-7, ZF-8). This can be interpreted as a consequence of the major influence on the chlorite composition of the $\mathrm{MgO}$ content in the system (e.g. whole rock), as noted by Xie et al. (1997). In fact, chlorite chemical compositions from samples ZF-3, ZF-7 and ZF-8 are similar to the chlorite chemical composition from the metapelitic sample C91-25 (see Fig. 8). Árkai et al. (2000) and Mata et al. (2001) showed how textural and mineralogical changes occur in a parallel manner, as a function of grade, in coeval pairs of metabasites and metapelites of a prograde sequence from the Bükk Mountains (Hungary), in spite of their very different bulk compositions, textures and original mineral assemblages. The principal difference was in the type of mixed layering in the two rock types.

Generally, chlorite crystallizes directly in pelitic rocks, and the typical transition from smectite to chlorite in basic rocks is not present. This can be explained as a consequence of the bulk-rock composition, because when the system is Fe-rich $(\mathrm{Fe}>\mathrm{Mg})$, as in pelites, mixed layering between smectite and chlorite is not present. Nevertheless, in basic systems, in which $\mathrm{Mg}>\mathrm{Fe}$, corrensite is formed during the smectite-chlorite transition (Shau et al., 1990). According to Jiang \& Peacor (1994) and Merriman et al. (1995) it is not necessarily the bulk-rock $\mathrm{Fe} / \mathrm{Mg}$ ratio that controls the production of corrensite in pelites but more critically this ratio in the mafic/ultramafic volcanic detritus, in which the smectite-chlorite transition occurs. In our case, basic lavas are anomalously richer in $\mathrm{Fe}$ with respect to $\mathrm{Mg}$ (see Table 1) and a similar behaviour to pelites can be expected. Under these Fe-rich conditions, as in the pelitic systems, chlorites would crystallize directly in diagenetic conditions without any smectite mixed layering.

Figure 8 demonstrates how the genuine composition of chlorite, i.e. when this mineral is free of contamination by smectite layers, is determined by the $\mathrm{Mg}$ content of the system, as proposed by Xie et al. (1997). This chemical parameter determines, via crystal-chemical constraints, all the chemical variables of chlorite which are closely related to each other when this mineral is the only principal $\mathrm{Fe} / \mathrm{Mg}$ phase (Fig. 6). Nevertheless, if another Fe/ Mg-rich mineral, such as epidote, is present, the chemical element distribution between minerals is affected significantly. Therefore, no relationship between the chemical composition of chlorite and metamorphic grade, independently of the mineral assemblage, can be invoked.

In conclusion, in very low-grade to diagenetic conditions of basic rocks, the absence of smectite or corrensite layers in the mafic phyllosilicates, deduced from the $X_{\mathrm{c}}$ parameter calculated with microprobe analyses, must be taken with several limitations. In these very low-grade conditions, the chemical composition of the system is a major controlling factor. When $\mathrm{Fe}>\mathrm{Mg}$ and a high $\mathrm{F} / \mathrm{FM}$ ratio is observed, the application of Cathelineau's empirical geothermometer must be excluded, because under these conditions no relationship between the genuine chlorite composition and metamorphic temperature can be expected.

\section{ACKNOWLEDGMENTS}

We thank T. Palacios for geological information on the samples and C. Laurin for revision of the English in the manuscript. Assistance by M.M. Abad-Ortega (Centro de Instrumentación Científica, University of Granada) with the HRTEM and AEM and by I. Nieto in the preparation of samples was essential for the completion of this work. We are grateful to R.J. Merriman and M.P. Mata for valuable comments on the manuscript. Financial support was supplied by Research Project BTE2000-0582 of the Spanish Ministry of Science and Technology, and Research Group RNM-0179 of the Junta de Andalucía.

\section{REFERENCES}

Aagaard P. \& Jahren J.S. (1992) Diagenetic illitechlorite assemblages in arenites. II. Thermodynamic relations. Clays and Clay Minerals, 40, 547-554. 
Aguirre L., Robinson D., Bevins R., Morata D., Vergara M., Fonseca E. \& Carrasco J. (2000) A low-grade metamorphic model for the Miocene volcanic sequences in the Andes of central Chile. New Zealand Journal of Geology and Geophysics, 43, 83-93.

Árkai P., Mata M.P., Giorgetti G., Peacor D.R. \& Tóth M. (2000) Comparison of diagenetic and low-grade metamorphic evolution of chlorite in associated metapelites and metabasites: an integrated TEM and XRD study. Journal of Metamorphic Geology, 18, 531-550.

Bettison L.A. \& Schiffman P. (1988) Compositional and structural variations of phyllosilicates from the Point Sal ophiolite, California. American Mineralogist, 73, 62-76.

Buseck P.R. (1992) Principles of transmission electron microscopy. Pp. 1-35 in: Minerals and Reactions at the Atomic Scale: Transmission Electron Microscopy (P.R. Buseck, editor). Reviews in Mineralogy, 27, Mineralogical Society of America, Washington, D.C.

Buseck P.R., Cowley J.M. \& Eyring, L. (1988) Highresolution Transmission Electron Microscopy and associated Techniques. Oxford University Press, New York, 128 pp.

Cathelineau M. (1988) Cation site occupancy in chlorites and illites as a function of temperature. Clay Minerals, 23, 471-485.

Cathelineau M. \& Nieva D. (1985) A chlorite solid solution thermometer. The Los Azufres geothermal system (Me). Contributions to Mineralogy and Petrology, 91, 235-244.

Champness P.E., Cliff G. \& Lorimer G.W. (1981) Quantitative analytical electron microscopy. Bulletin of Mineralogy, 104, 236-240.

Cliff G. \& Lorimer G.W. (1975) The quantitative analysis of thin specimens. Journal of Microscopy, 103, 203-207.

De Caritat P.D., Hutcheon I. \& Walshe J.L. (1993) Chlorite geothermometry: a review. Clays and Clay Minerals, 41, 219-239.

Essene E.J. \& Peacor D.R. (1995) Clay minerals thermometry - A critical perspective. Clays and Clay Minerals, 43, 540-553.

Frimmel H.E. (1997) Chlorite thermometry in the Witwatersrand Basin: constraints on the Paleoproterozoi c geotherm in the Kaapvaal Craton, South Africa. Journal of Geology, 105, 601-615.

Hutcheon I. (1990) Clay-carbonate reactions in the Venture area, Scotia Shelf, Nova Scotia, Canada. Pp. 199-212 in: Fluid-mineral Interactions: A Tribute to H.P. Eugster (R.J. Spencer \& I.M. Chou, editors). Special Publication 2, Geochemical Society, Washington, D.C.

Jiang W.W. \& Peacor D.R. (1994) Prograde transition of corrensite and chlorite in low-grade pelitic rocks from the Gaspe Peninsula, Quebec. Clays and Clay
Minerals, 42, 497-517.

Jiang W.W., Peacor D.R. \& Buseck P.R. (1994) Chlorite geothermometry? - contamination and apparent octahedral vacancies. Clays and Clay Minerals, 42, 593-605.

Jowett E.C. (1991) Fitting iron and magnesium into the hydrothermal chlorite geothermomete $\mathrm{r}$ (abstract). GAC/MAC/SEG Joint Annual Meeting. Program and Abstracts, 16, A62.

Julivert M., Fontboté J.M., Ribeiro A. \& Conde L. (1974) Mapa Tectónico de la Península Ibérica y Baleares. Instituto Geológico y Minero de España, Madrid, Spain, 113 pp.

Kranidiotis P. \& McLean W.H. (1987) Systematics of chlorite alteration at the Phelps Dodge massive sulfide deposit. Matagami, Quebec. Economic Geology, 82, 1898-1991.

Laird J. (1988) Chlorites: metamorphic petrology. Pp. 405-453 in: Hydrous Phyllosilicates (Exclusive of Micas) (S.W. Bailey, editor). Reviews in Mineralogy, 19, Mineralogical Society of America, Washington, D.C.

Liñán E., Gámez-Vintaned J.A., Palacios T., Álvaro J., Gonzalo R., Mayoral E., Moreno-Eiris E., Perejón A., Quesada C. \& Sánchez-García T. (1995) The Cambrian of the Alconera Unit. NeoproterozoicCambrian Transet of Sierra Morena and Montes de Toledo. Pre-conference Field Guide. Pp. 9-21 in: Annual IGCP Project 319 Meeting, Regional IGCP Project 320 Meeting and XIII Geological Meeting on the West of Iberia Peninsula, University of Salamanca, Spain.

López-Munguira A. \& Nieto F. (2000) Transmission electron microscopy study of very low-grade metamorphic rocks in Cambrian sandstones and shales, Ossa-Morena zone, South-West Spain. Clays and Clay Minerals, 48, 213-223.

López-Munguira A., Nieto F. \& Sebastian-Pardo E. (1993) Caracterización de las pizarras cámbricas de la Unidad Alconera (Zona de Ossa-Morena). Su utilidad como indicadores de las condiciones metamórficas. Geogaceta, 13, 69-71.

López-Munguira A., Morata D. \& Nieto F. (1996) Geoquímica de los materiales pelíticos cámbricos al noroeste de Zafra (Badajoz). Geogaceta, 22, $149-152$.

López-Munguira A., Nieto F. \& Morata D. (1998) Metamorphic evolution from diagenesis to epizone in Cambrian formations from NW Zafra (OssaMorena zone, SW Spain). Neues Jahrbuch für Mineralogie Abhandlungen, 174, 131-157.

Mata M.P., Giorgetti G., Árkai P. \& Peacor D.R. (2001) Comparison of evolution of trioctahedral chlorite/ berthierine/smectite in coeval metabasites and metapelites from diagenetic to epizonal grades. Clays and Clay Minerals, 49, 318-332.

Merriman R.J. \& Peacor D.R. (1999) Very low-grade 
metapelites. Mineralogy, microfabric s and measuring reaction progress. Pp. 10-58 in: Low-grade Metamorphism. (M. Frey \& D. Robinson, editors). Blackwell Science. Oxford, UK.

Merriman R.J., Roberts B., Peacor D.R. \& Hirons, S.R. (1995) Strain-related differences in the crystal growth of white mica and chlorite: a TEM and XRD study of the development of metapelite microfabrics in the Southern Uplands thrust terrene, Scotland. Journal of Metamorphic Geology, 13, 559-576.

Sagredo J. \& Peinado M. (1992) Vulcanismo Cámbrico de la Zona de Ossa-Morena. Pp. 567-576 in: Paleozoico Inferior de Iberoamérica. (J.G. Gutiérrez-Marco, J. Saavedra \& I. Rábano, editors). Universidad de Extramadura, Badajoz, Spain.

Schiffman P. \& Day H.W. (1999) Petrological methods for the study of very-low grade metabasites. Pp. 108-142 in: Low-grade Metamorphism (M. Frey \& D. Robinson, editors). Blackwell Science, Oxford, UK.

Schmidt D. \& Livi K.J.T. (1999) HRTEM and SAED investigations of polytypism, stacking disorder, crystal-growth, and vacancies in chlorites from subgreenschist facies outcrops. American Mineralogist, 84, 160-170.

Schmidt D., Livi K.J.T. \& Frey M. (1999) Reaction progress in chloritic material - an electron microbeam study of the Taveyanne Greywacke, Switzerland. Journal of Metamorphic Geology, 17, 229-241.

Schmidt S.Th. \& Robinson D. (1997) Metamorphic grade and porosity and permeability controls on mafic phyllosilicate distribution $\mathrm{s}$ in a regional zeolite to greenschist facies transition of the North Shore Volcanic Group, Minnesota. Geological Society of America Bulletin, 109, 683-697.

Shau Y.H., Peacor D.R. \& Essene E.J. (1990) Corrensite and mixed-layer chlorite/corrensite in metabasalt from northern Taiwan: TEM/AEM, EMPA, XRD, and optical studies. Contributions to Mineralogy and Petrology, 105, 123-142.

Walker J.R. (1993) Chlorite polytype geothermometry . Clays and Clay Minerals, 41, 260-267.

Walshe J.L. (1986) A six-component chlorite solid solution model and the conditions of chlorite formation in hydrothermal and geothermal systems. Economic Geology, 81, 681-703.

Warren E.A. \& Ransom B. (1992) The influence of analytical error upon the interpretation of chemical variation in clay minerals. Clay Minerals, 27, 193-209.

Xie X., Byerly G.R. \& Ferrell R.E. (1997) IIb trioctahedral chlorite from the Barberton greenstone belt: crystal structure and rock composition constraints with implications for geothermometry. Contributions to Mineralogy and Petrology, 126, 275-291.

Zane A., Sassi R. \& Guidotti C.V. (1998) New data on metamorphic chlorite as a petrogenetic indicator mineral, with special regard to greenschist-facie s rocks. The Canadian Mineralogist, 36, 713-726.

Zang W. \& Fyfe W.S. (1995) Chloritization of the hydrothermally altered bedrock at Igarapé Bahia gold deposits, Carajás, Brazil. Mineralium Deposita, 30, 30-38. 